\title{
DEVELOPMENT OF AN ENVIRONMENTALLY FRIENDLY SCHEME FOR THE RECOVERY OF USED ENGINE OILS
}

\section{РОЗРОБКА ЕКОЛОГІЧНО БЕЗПЕЧНОЇ СХЕМИ ВІДНОВЛЕННЯ ВІДПРАЦЬОВАНИХ МОТОРНИХ ОЛИВ}

\author{
Yuliia Zelenko ${ }^{1}$ \\ Maryna Bezovska ${ }^{2}$
}

DOI: https://doi.org/10.30525/978-9934-588-15-0-55

Abstract. Waste generation is a significant problem for Ukraine's rail transport. The simplest methods used today for the recovery of waste oils on the railways do not give a full effect; therefore, it is more rational to use the latest developments that will quickly pay off and give a significant ecological and economic effect. We have developed and proposed a scheme for the recovery of waste oils. When developing the general scheme for restoring the operational quality of the used engine oils, we proceeded from the results of the performed laboratory tests on different purification methods and an optimized variant of the chosen technology. Considerable attention was also paid to the ecologo-toxicological side of this issue. After all, used petroleum products are toxic waste, which have a low biodegradation degree $(10-30 \%)$. The toxicity of petroleum products is determined by the combination of hydrocarbons that are part of their composition. It should be noted that the main compounds that form the negative toxicological profile of oily waste (including waste oils) are benz $(\alpha)$ pyrene, furans, dioxins, polychlorinated biphenyls, and others. The main recommendation of the international community for the composition of oils from this point of view is the absence of heavy metals and chlorinated compounds in them. That is why we checked the fresh, used and recovered oils according to the proposed scheme for the content of benz $(\alpha)$ pyrene, heavy metals and chloride ions. After comparing the environmental indicators of fresh, discarded and

\footnotetext{
${ }^{1}$ Professor, Head of the Department of Chemistry and Environmental Engineering,

Senior Researcher Laboratory "Ecology in rail transport",

Dnipro National University of Railway Transport named after Academician V. Lazarian, Ukraine

${ }^{2}$ Associate Professor of the Department of Chemistry and Environmental Engineering,

Dnipro National University of Railway Transport named after Academician V. Lazarian, Ukraine
}

(C) Yuliia Zelenko, Maryna Bezovska 
recovered oils we found that chloride ions are absent at all stages; also, when working with the oils of both brands there appears a benz $(\alpha)$ pyrene, which completely disappears from the oils after processing them according to the proposed schemes; a significant reduction in the amount of toxic elements after the treatment of oils according to the proposed schemes confirms the safety of recovered oils and the ecological compatibility of the schemes. Thus, the implementation of the proposed scheme will return valuable raw materials (oil) to the process cycle, will create almost non-waste production of recovered oils, as well as promote the creation of a non-waste production-territorial complex on the basis of the linear unit of the railway, which will give an opportunity to obtain significant economic effect.

\section{1. Вступ}

Одними 3 найактуальніших проблем сучасного розвитку науково-технічного прогресу є проблема охорони навколишнього середовища від забруднень, утворення відходів виробництва та споживання і раціонального використання природних ресурсів. Зокрема значною проблемою є утворення нафтовмісних віходів різних галузей промисловості. Так, для залізничного транспорту - це одне з найгостріших екологічних питань.

Відповідно до прийнятих рішень, відпрацьовані нафтопродукти підлягають обов'язковому збору та утилізуванню, а в окремих випадках і знищенню. Найбільш ефективним способом утилізування є регенерація - вторинна переробка відпрацьованих олив 3 метою повного відновлення їхніх первинних властивостей, яке здійснюється, як правило, шляхом складної багатостадійної переробки на спеціалізованих підприємствах. Постійна поява нових способів і засобів рішення завдань утилізування, створення все досконаліших, безвідхідних методів регенерації відпрацьованих мастильних матеріалів, питання екології та охорони здоров'я людини викликають необхідність постійної уваги до даної проблеми, що перебуває на стику техніки, екології та економіки.

Для більшості держав регенерація з отриманням кондиційних мастиль-них матеріалів є найкращою можливістю організувати в країні на власній сировинній базі виробництво цієї важливої для багатьох сфер народного господарства продукції. Крім того, регенерація 
дозволяє ефективно позбутися від небезпечних відходів виробництва, уникнувши при цьому витрат на їхнє знищення, заощадити природні й трудові ресурси, капіталовкладення, матеріали й електроенергію, підвищити ступінь забезпеченості держави власними ресурсами за рахунок використання вторинних.

Метою нашого дослідження є як пошук можливостей зменшення навантаження на навколишнє природне середовище шляхом розробки новітніх схем поводження з нафтовміщуючими відходами, так і дослідження їх токсикологічного профілю на всіх етапах - від моменту утворення до перевірки безпеки після утилізування.

\section{2. Токсичність нафтовміщуючих відходів}

Відпрацьовані нафтопродукти є токсичними відходами, які мають невисокий ступінь біорозкладання (10-30\%). Токсичність нафтопродуктів визначається сполученням вуглеводнів, які входять до їх складу. Зокрема арени є найсильнішими канцерогенами у складі нафтопродуктів, також значну токсичну дію мають олефіни, сполуки сірки, азоту та кисню. Особливо негативну дію відпрацьовані нафтопродукти мають на центральну нервову та серцево-судинну системи людини, ендокринний апарат організму, знижують гематологічні показники, викликають ураження печінки та щитовидної залози [1, с. 188, 2, p. 1081-1082].

Велику шкоду відпрацьовані нафтопродукти спричиняють і навколишньому природному середовищу і особливо водним ресурсам. Так, за оцінками експертів один літр відпрацьованої оливи може забруднити близько семи мільйонів літрів грунтових вод. Вплив нафтовміщуючих відходів на довкілля і людину показаний на рисунку 1.

Нафтові оливи (мінеральні оливи) - це рідкі суміші алкілнафтенових і алкілароматичних вуглеводнів (температура кипіння 300-600들 ють шляхом переробки нафти. Відпрацьованою вважається нафтова олива, що відпрацювала свій термін або втратила у процесі експлуатації якість, встановлену нормативно-технічною документацією, і злита з робочої системи.

Хімічна композиція відпрацьованого мастильного матеріалу варіює у залежності від характеристик вихідної сировини, технології перегонки нафти, продуктивності і типу двигуна, у якому ці оливи 


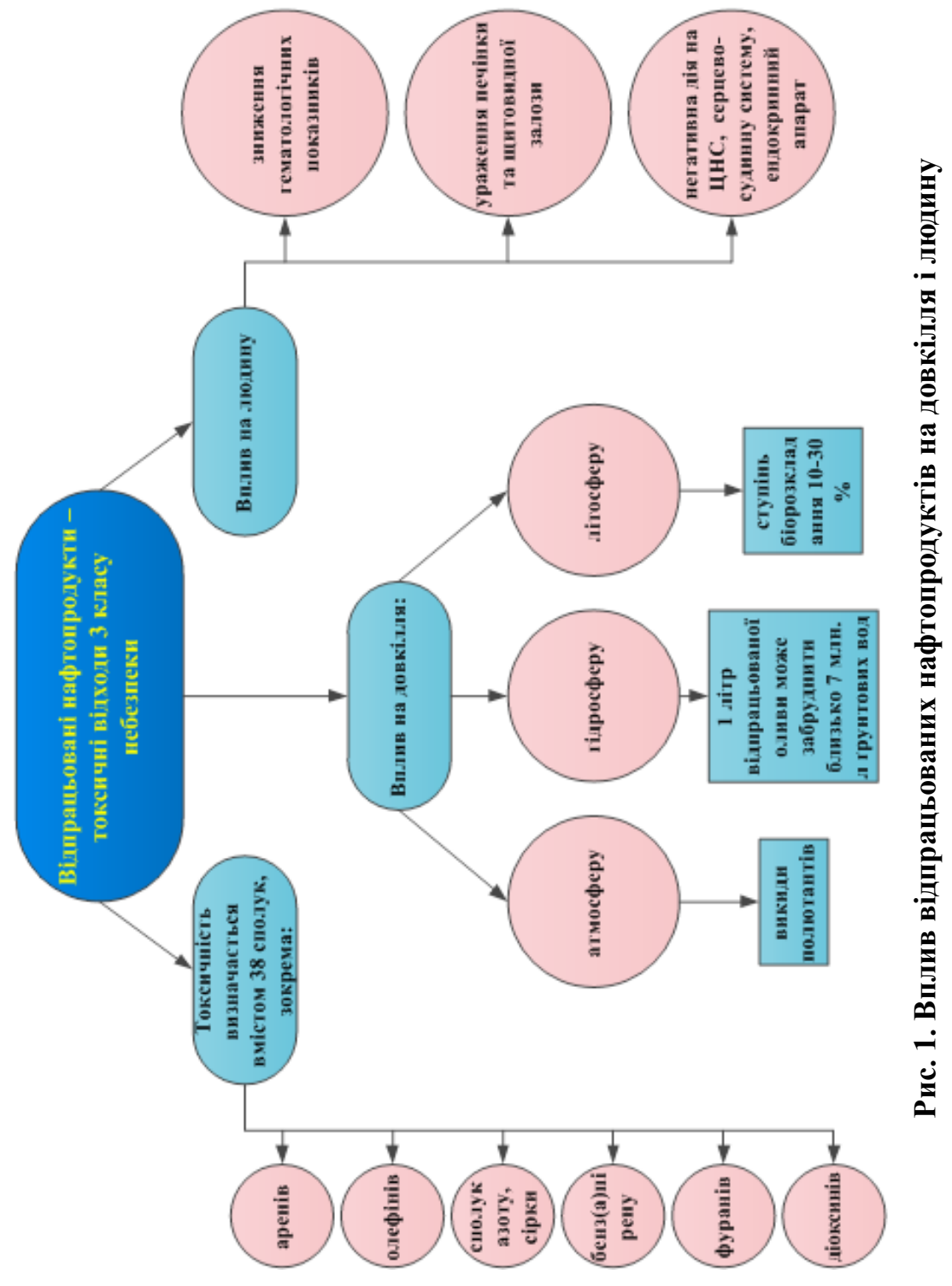


використовуються, складу присадок, тривалості часу, протягом якого оливи експлуатуються у двигуні. Відмічається, що найбільша концентрація важких металів, механічних домішок, забруднень спостерігається у моторних оливах, що накопичуються у відпрацьованих оливних фільтрах.

В одиниці маси відпрацьованого мастильного матеріалу міститься у середньому 73-80\% аліфатичних вуглеводнів (головним чином алканів (парафінів) і циклоалканів з 1-6 кільцями), 11-15\% моноароматичних вуглеводнів, 2-5\% діароматичних вуглеводнів, 4-8\% поліароматичних вуглеводнів [1, с. 188].

Головним чином, токсичність відпрацьованих олив зростає через поступове збільшення вмісту бенз $(\alpha)$ пірену, і це у значній мірі визначає третій клас токсичності цих відходів. Вміст у відпрацьованих оливах бенз $(\alpha)$ пірену в більшості країн служить показником їхньої небезпеки, оскільки сумарна токсична дія бенз $(\alpha)$ пірену приблизно в 10000 разів вище, ніж в оксидів азоту, що також утворюються у працюючих оливах. Вміст бенз $(\alpha)$ пірену може збільшуватися до 15 мг/кг (загальний вміст поліциклічних аренів до 482 мг/кг), а частка від загальної канцерогенності відпрацьованої оливи становить $18 \%$.

Речовини, що містяться у відпрацьованих оливах, здатні накопичуватися в грунті й атмосфері, можуть негативно впливати на імунну систему людини, функціонування внутрішніх органів, мають ембріота генотоксичну дію, викликають дисбаланс статевих гормонів [1, c. 189,3 . с. 9].

Також варто зазначити, що до складу композицій мастильних олив 3 метою поліпшення їх функціональних властивостей вводяться компоненти, які характеризуються певними токсикологічними властивостями. До таких компонентів можна віднести функціональні присадки, що додаються до основ олив 3 метою поліпшення їх ефективності: протизношувальної, протизадирної (совол, трикрезилфосфат); захисної (бензотриазол); антиокисної (параоксидіфеніламін, феніл- $\alpha$-нафтиламин, іонол).

Саме тому відпрацьовані нафтопродукти і зокрема відпрацьовані оливи були віднесені світовим співтовариством до категорії небезпечних відходів. 


\section{3. Міжнародні домовленості}

Відпрацьовані оливи містять у своєму складі за різними оцінками близько 38 хімічних сполук, що мають мутагенну та канцерогенну дію. Серед цих сполук, крім бенз( $\alpha)$ пірену, треба виділити фурани, діоксини, поліхлордіфеніли та інші. Останні дві сполуки включені Стокгольмською конвенцією у список дванадцяти найтоксичніших стійких органічних забруднювачів планети [3, с. 8-9].

Тому на своїй третій нараді конференція сторін Стокгольмської конвенції, яка пройшла з 30 квітня по 4 травня 2007 року в Дакарі (Сенегал), своїм рішенням прийняла оновлений проект керівних принципів по найкращим наявним методам (HНM) і попереднім вказівкам по найкращим видах природоохоронної діяльності (НВПД).

Хімічні речовини, що були зазначені в Стокгольмській конвенції, включають: поліхлорований дібензо-п-діоксини (ПХДД), поліхлоровані дібезофурани (ПХДФ), поліхлоровані біфеніли (ПХБ) і гексахлорбензол (ГХБ). Ці речовини, крім того, що вони є речовинами 3 документованою токсичністю, є достатньо стійкими, здатні до біоакумуляції і перенесення на великі відстані. У керівних принципах і вказівках вказані процеси, які ведуть до ненавмисного утворення і викиду цих речовин, а також їх вплив на людину і навколишнє середовище. Крім того, перераховані ефективні заходи для запобігання викидам цих речовин. Так, серед інших до них віднесені:

- використання маловідхідної технології;

- використання менш небезпечних хімічних речовин;

- сприяння розповсюдженню практики рекуперації і рециркуляції відходів і речовин, які утворюються і використовуються в межах того або іншого процесу;

- заміна матеріалів в тих випадках, коли вони є стійкими органічними забруднювачами або коли є безпосередній зв'язок між матеріалами і викидами стійких органічних забруднювачів з джерела;

- раціональне господарювання і програми в області профілактичного ремонту;

- удосконалення методів регулювання відходів в цілях припинення відкритого або іншого неконтрольованого спалювання відходів, включаючи спалювання звалищ сміття. При розгляді пропозицій про будівництво нових установок по видаленню відходів увагу слід приді- 
ляти таким альтернативам, як заходи щодо максимального скорочення утворення різних типів відходів, включаючи відновлення ресурсів, повторне використання, рециркуляцію, розділення відходів і сприяння використанню продуктів, які приводять до утворення меншого об'єму відходів. На основі цього підходу повинні ретельно розглядуватися питання охорони здоров'я людини;

- максимальне скорочення цих речовин, присутніх в продуктах у вигляді забруднювачів;

- необхідність уникати використання елементарного хлору або хімічних речовин, що включають елементарний хлор [3, с. 9-10].

Окрім Стокгольмської конвенції існує також ще одне глобальна угода, а саме Базельська конвенція щодо контролю за транскордонним перевезенням небезпечних відходів і їх видаленням, яка була прийнята в 1989 році і набрала чинності 1992 року. Базельська конвенція накладає на країни-учасниці зобов'язання, поміж інших, по мінімізації виробництва небезпечних відходів; забезпеченню адекватних установок по утилізуванню; а також забезпеченню екологічно безпечного управління відходами.

Конференція сторін Базельської конвенції на своєму восьмому засіданні в грудні 2006 року прийняла оновлений варіант загальних технічних вказівок по екологічно обгрунтованому управлінню відходами, що складаються із стійких органічних забруднювачів, а також оновлений варіант вказівок по екологічно обгрунтованому поводженню 3 відходами, що складаються з поліхлорованих біфенілів, поліхлорованих терфенілів або полібромованих біфенілів, відходами, що містять ці речовини, або відходами, забрудненими цими речовинами.

Підприємства по переробці відпрацьованих олив наводяться в Стокгольмській конвенції як потенційне джерело утворення і викидів хімічних речовин. Виявилося, що відпрацьовані оливи можуть бути забруднені поліхлорованим дібензо-п-діоксинами (ПХДД), поліхлорованими дібензофуранами (ПХДФ) і поліхлорованими біфенілами (ПХБ).

Зазначено, що в даний час немає свідоцтв того, що на підприємствах по переробці відпрацьованих олив відбувається новоутворення ПХДД/ПХДФ або ПХБ. Наявні дані свідчать, що викиди ПХДД/ ПХДФ і ПХБ підприємствами по переробці відпрацьованих олив або підприємствами по їх транспортуванню і утилізуванню відбуваються 
в результаті промислового, спеціального виробництва ПХБ або хлорбензолів, які потрапляють у відпрацьовані оливи як забруднювачі або в процесі синтезу (цих хімічних речовин), або в процесі використання або попередньої рециркуляції. У цьому сенсі підприємства по переробці відпрацьованих олив $\epsilon$ не джерелом формування хімічних речовин, а швидше джерело їх розповсюдження.

Згідно наявної інформації, варіанти утилізування відпрацьованих олив включають: повторне використання або регенерацію, термічний крекінг, і спалювання або використання як паливо. Слід зазначити, що в багатьох країнах також практикується скидання на звалище і відкрите спалювання.

Так як на підприємствах по переробці відпрацьованих олив саме відпрацьовані оливи є основними джерелами забруднення ПХДД/ ПХДФ і ПХБ, єдиною основною мірою по скороченню емісій ПХДД/ ПХДФ і ПХБ на таких підприємствах є переробка відпрацьованих олив з низькими концентраціями ПХДД/ПХДФ і ПХБ. Регенерована олива має містити не більше 50 мільйонних часток (мг/л) полі хлорованих біфенілів та трифенілів.

Свропейська асоціація промисловості повторного очищення (Groupement Europeen de l'Industrie de la Regeneration; GEIR) рекомендує, щоб при регенерації перевага віддавалася тим видам відпрацьованих олив, що не містять хлор [3, с. 11].

У країнах Європейського Союзу на сьогодні діє директива Ради 75/439/ЕЕС, спрямована на утворення уніфікованої системи збирання, переробки, зберігання та видалення відпрацьованих олив. Директива дозволяє країнам-членам ЄС компенсувати компаніям витрати на збирання та видалення відпрацьованих олив.

Найбільш пріоритетним вважається регенерація відпрацьованих олив, а не їх спалення; менш пріоритетним - їх знищення, контрольоване зберігання або заховання. Країни-члени СС мають забезпечувати безпечне збирання та видалення відпрацьованих олив. Заборонено скидати такі відходи у водні об'єкти або дренажні системи.

Будь-яке підприємство, що займається видаленням відпрацьованих олив, повинне отримати дозвіл від компетентного органу. А підприємства, що займаються збиранням відпрацьованих олив, мають проходити реєстрацію та контролюватися [3, с. 11; 4, р. 1300-1301; 5, с. 15; 
6, p. 263-264]. Існують спеціально розроблені паспорти безпеки хімічної продукції, до якої відносяться і нафтопродукти. В таких паспортах обов'язково присутній розділ, що містить екологічну інформацію, зокрема:

- оцінку можливих потенційних впливів на навколишнє середовище;

- найбільш важливі характеристики впливу хімічної продукції на навколишнє середовище.

До останнього пункту відносять інформацію щодо хімічної, біологічної трансформації, здатності до біокумуляції, персистентності і біодеградації (розкладання), дані по екотоксичність, гігієнічні нормативи в різних сферах. Також там повинна бути приведена інформація щодо будь-яких інших несприятливих впливах на навколишнє середовище, таких як загибель флори, фауни, корозія грунтів, спустелювання території, можливе руйнування озонового шару землі, глобальне потепління клімату.

В Україні поводження з відпрацьованими нафтопродуктами підпадає під дію ряду міжнародних директив та внутрішніх правил залізничної інфраструктури (рисунок 2).

\section{4. Сучасний стан проблеми на залізниці}

По використанню моторних олив та палив на першому місці в Україні знаходиться Дніпропетровська область. Якщо аналізувати по галузях економіки, то перше місце належить сільському господарству (на нього приходиться $35,4 \%$ від загального використання різних типів олив), залізничний транспорт разом з автомобільною промисловістю та транспортними засобами знаходиться на четвертому місці (13\%). В цілому по оцінкам експертів використання олив суттєво зростає 3 кожним роком.

Аналіз сучасного стану проблеми у сфері поводження з нафтовміщуючими відходами показав, що вона гостро постала і перед лінійними підрозділами залізниць України [3, с. 52; 4, p. 1300; 6, p. 264; 7, p. 8]. Так, згідно статистичних даних залізничних підприємств, поміж інших відходів значними об'ємами утворення відрізняються технологічні шлами і відпрацьовані оливи, які $є$ небезпечним джерелом аренів, важких металів, бенз(а)пірену, олефінів, сполук сірки, азоту та ін. 
Yuliia Zelenko, Maryna Bezovska

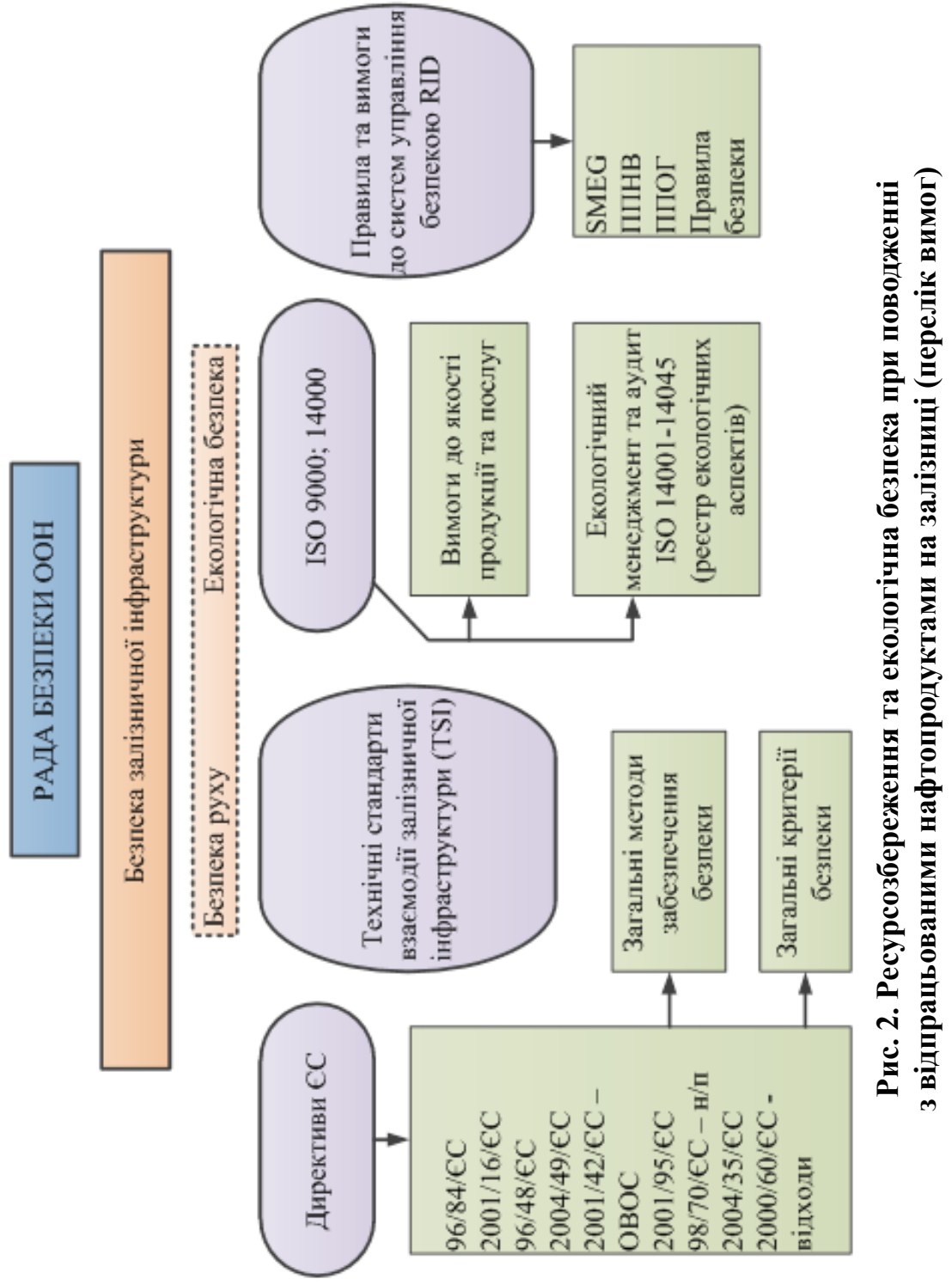


Наприклад, нафтовміщуючі шлами лінійних підрозділів залізниць накопичуються у стічних водах підприємств після обмивки вагонів, тепловозів та їх деталей, тому найбільша їх кількість утворюється у вагонних і пасажирських депо залізниць, т. я. саме тут проводять обмивку рухомого складу при проведенні ремонтних робіт.

Зовні відходи технологічних шламів представляють собою масу коричневого кольору, яка має грудкувату структуру. Нафтошлами відрізняються різноманітним складом; в них присутні нафта, вода, нафтові емульсії, асфальтени, гудрони, іони важких металів, різноманітні механічні домішки та радіоактивні елементи. Найчастіше технологічні шлами відносяться до третього класу небезпечності і являються помірно небезпечними. Цей клас небезпеки обумовлюється вмістом у цих відходах ряду важких металів, зокрема свинцю, цинку, нікелю та інших (таблиця 1).

Таблиця 1

Аналіз технологічного шламу, що зазвичай утворюсться на залізничних підприємствах

\begin{tabular}{|c|c|c|c|}
\hline \multirow{2}{*}{$\begin{array}{c}\text { Вміст металу, } \\
\text { мг/кг, клас } \\
\text { небезпечності }\end{array}$} & Валова & Рухома & $\begin{array}{c}\text { Вміст у відходах, } \\
\text { кг/т }\end{array}$ \\
\hline $\mathrm{Pb}(1)$ & 37 & 0 & 0,037 \\
\hline $\mathrm{Zn}(2)$ & 23,8 & 6,2 & 0,023 \\
\hline $\mathrm{Ni}(2)$ & 13 & 3,5 & 0,013 \\
\hline $\mathrm{Cu}(2)$ & 5 & 2 & 0,005 \\
\hline $\mathrm{Cr}(2)$ & 10 & 0 & 0,01 \\
\hline $\mathrm{Mn}(3)$ & 8,8 & 3,5 & 0,008 \\
\hline
\end{tabular}

Моторні оливи в процесі роботи в двигуні внутрішнього згоряння значно змінюють свої властивості з наступних причин:

1. «виснажуються» присадки, наприклад, миючі сприяють потемнінню кольору оливи, загущуючі присадки розриваються на дрібні молекули, що призводить до зменшення в'язкості оливи.

2. Олива окиснюється під дією кисню повітря (молекули оливи поєднуються з ним і темніють з утворенням смолистих речовин).

3. До оливи потрапляють механічні домішки і продукти згоряння. 
4. Відбувається обводнення, що сприяє розвитку корозійних процесів.

Відсутність на залізницях устаткування для утилізації цих відходів та зменшення їх негативного впливу на довкілля вказує на необхідність розроблення сучасної адаптованої до умов виробничого процесу технології, за допомогою якої можна було б скоротити обсяги цих відходів і тим самим зменшити масштаби їх впливу на навколишнє природне середовище. В результаті ії впровадження можна отримати значні як екологічні, так і економічні ефекти [7, p. 8-10; 8, p. 1095; 9, p. 177; 10, p. 1341].

Нами був проведений аналіз різних характеристик олив, що використовуються на тяговому рухомому складі залізниць України. В результаті аналізу обсягів утворення виявлено, що у найбільшій кількості ці оливи використовуються підприємствами локомотивної служби, і відповідно ці підрозділи є найбільшими вкладниками в утворення оливовмісних відходів.

Утворення відходів на підприємствах локомотивної служби (у процентному співвідношенні за рік) зображено на рисунку 3, на якому можна побачити, що оливи є на таких підприємствах основними за кількістю відходами.

Так, при заміні оливи з одного тепловоза зливають близько 550 кг відпрацьованої моторної оливи (для тепловозів типу ЧМЭЗ). У залежності від кількості одиниць рухомого складу, що обслуговуються в локомотивному депо, та об'ємів виробництва залізничного підприємства за рік в депо може утворюватися до 100 т відпрацьованої оливи.

Моторна олива - це один із найважливіших елементів у конструкції двигуна, який призначений для довгострокової та надійної підтримки його роботи, забезпечення заданого ресурсу двигуна. Виконання цих функцій можливе лише при точній відповідності їі властивостей тим термічним, механічним і хімічним впливам, яким олива піддається в процесі роботи, а саме в оливній системі двигуна, на поверхнях, що змащуються та охолоджуються. Взаємна відповідність конструкції двигуна, умов його експлуатації і властивостей оливи - одна 3 найважливіших умов досягнення високої надійності двигунів.

Свіжа моторна олива на вигляд являє собою прозору, в'язку рідину, що складається з базової сировини і присадок до неї.

У процесі роботи олива поступово забруднюється різноманітними металевими часточками, що потрапляють у неї в результаті стирання 


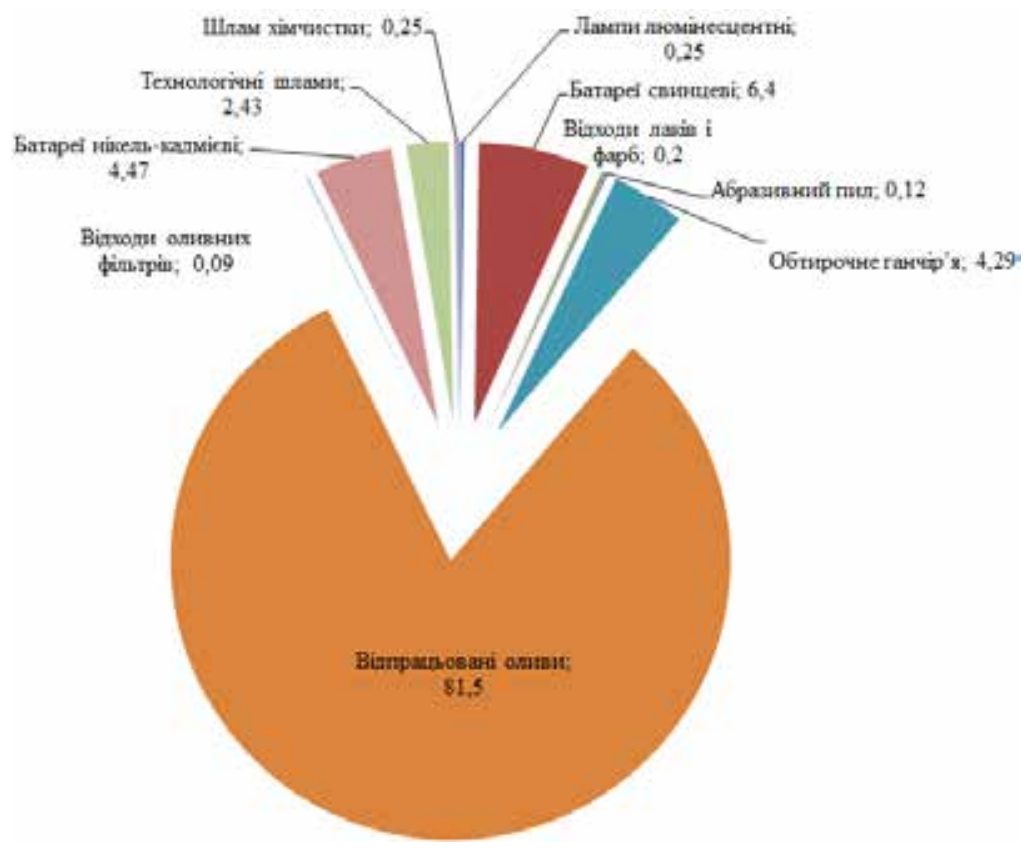

Рис. 3. Утворення відходів на підприсмствах локомотивної служби у процентному співвідношенні за рік

металевих поверхонь деталей, мінеральними домішками, які опиняються в оливній системі через повітря та можуть викликати інтенсивне зношування обладнання, розріджується пальним, що значно знижує іiі температуру спалаху, адгезію та в'язкість. Неповне згоряння палива викликає потрапляння у картер смолисто-сажистих часток, що забруднюють оливу та інтенсифікують лако- і нагароутворення.

Крім того, в оливу із продуктів згоряння палива, навколишнього повітря, нещільності у водяних охолоджуючих приладах може потрапляти вода; присутність іiі дуже негативно впливає на такі властивості олив, як корозійна стійкість, стійкість до окиснення. При потраплянні води руйнується оливна плівка в підшипниках колінчастого валу i антифрикційний шар підшипників, посилюється зношення і корозія деталей двигунів, з'являються згустки, які забивають оливопровід 
та ускладнюють потрапляння оливи до деталей. Також вода утворює стійку емульсію 3 оливою, що не тільки погіршує якість оливи, а й ускладнює іiї подальшу регенерацію.

Через взаємодію 3 нагрітими частинами обладнання олива зазнає термічного розкладення, також вона окислюється під дією кисню повітря. Деякі метали, наприклад, залізо, свинець, цинк та інші, можуть виступати каталізаторами процесу окиснення. Пришвидшувати окиснення може і вода. Окрім процесів розкладання та окиснення паралельно можуть іти вторинні процеси полімеризації та конденсації.

Деякі продукти окиснення та ущільнення (асфальтени, карбоїди) нерозчинні в оливі; вони можуть утворювати колоїдні системи та випадати в осад у вигляді шламоподібних продуктів і поступово забруднювати оливопроводи, порушувати циркуляцію оливи, викликати утворення нагару.

Також на оливу діють такі фактори навколишнього середовища, як тиск, електричне поле та природне освітленням [3, с. 53-57; 11, с. 82-83].

Як результат, олива повністю змінює свої характеристики, втрачає основні експлуатаційні властивості і стає дуже густою мулоподібною речовиною чорного або темно-коричневого кольору, густою сумішшю різного роду рідин з добавками твердих речовин - оксидів металів, продуктів зносу.

На підприємствах залізничного транспорту для тягового рухомого складу існує певний перелік бракувальних норм - числових значень параметрів якості, при досягненні яких мастильні матеріали втрачають функціональні властивості.

Дані аналізів порівнюють з бракувальними показниками і таким чином оцінюють експлуатаційну придатність оливи. Олива, що не набула бракувальних параметрів може використовуватись у подальшому; до того моменту, доки хоча б один із бракувальних показників не буде перевищений таку оливу вважають експлуатаційною, тобто такою, що в повній мірі забезпечує надійну роботу двигуна.

Відбракована і злита з картера при плановій заміні олива підлягає передачі на регенерацію. Після вивчення існуючих технологій та схем регенерації відпрацьованих моторних олив на залізничному транспорті України було з'ясовано, що заходів по відновленню відпрацьованих олив майже не проводиться, а ті найпростіші фізичні методи, що існують, мають низький ефект очистки і вихід очищеного продукту, а тому вимагають удосконалення. 


\section{5. Розроблення схеми поводження з відпрацьованими оливами}

Проаналізувавши ситуацію, яка склалася, ми прийшли до висновку, що відсутність на залізницях устаткування для утилізації цих відходів та зменшення їх негативного впливу на довкілля вказує на необхідність розроблення сучасної адаптованої до умов виробничого процесу технології, за допомогою якої можна було б скоротити обсяги цих відходів і тим самим зменшити масштаби їх впливу на навколишнє природне середовище. В результаті ії впровадження можна отримати значні як екологічні, так і економічні ефекти.

Після аналізу існуючих напрямків підвищення рівня екологічної безпеки при поводженні з відпрацьованими оливами та узагальнення робіт, присвячених розробленню природоохоронних заходів 3 метою зниження техногенного навантаження, спричиненого їх впливом на довкілля, були проведені експериментальні дослідження по відновленню олив 3 використанням різних методів. Зокрема випробувані найпростіші фізичні методи, методи 3 використанням сорбентів різного походження (цеолітів, керамзиту, діалюмінію триоксиду), експерименти з використанням класичного сульфатнокислотного методу очищення відпрацьованих олив, випробуваний метод очищення відпрацьованих олив з використанням різних типів поверхнево-активних речовин (ПАР).

Найкращий результат було досягнено сумісним використанням ПАРи неонолу та алкілбензосульсокислоти (АБСК) - замінника сульфатної кислоти. Так, для оливи М-14В2, яка широко застосовується на залізниці, ефект очистки склав 95,08\%; при цьому максимальний вихід очищеної оливи при цьому склав $90,01 \%$ [3, с. $87 ; 12$, с. 19-20].

В результаті була запропонована схема поводження 3 оливами, надані рекомендації щодо поводження $з$ ними після відбракування (рисунок 4). Основні складові запропонованої схеми це ємкість-усереднювач, ємкості для зберігання основних реагентів, змішувачі, центрифуга, насоси-дозатори, нафтошламонакопичувач.

При розробці загальної схеми відновлення експлуатаційної якості відпрацьованих моторних олив ми виходили з результатів проведених лабораторних досліджень по випробуванню різних методів очищення та оптимізованого варіанту обраної технології, а саме з температурних умов, кількості реагентів та часу їх контактування з оливою. 
Yuliia Zelenko, Maryna Bezovska

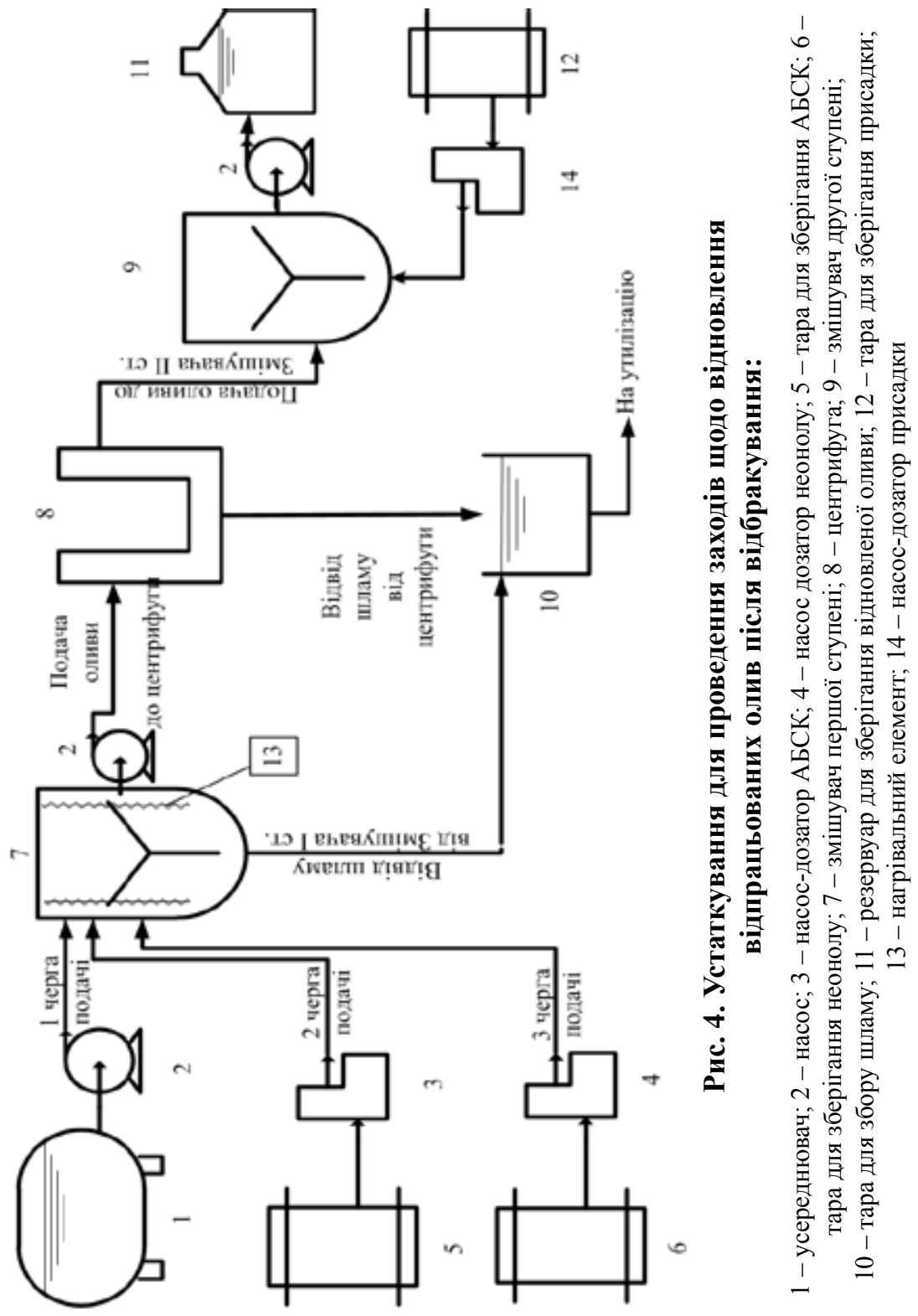




\section{6. Вивчення токсикологічних властивостей олив}

Як вже зазначалось вище, основні токсикологічні властивості нафтовмісних відходів, зокрема відпрацьованих олив, обумовлюються такими сполуками, як бенз $(\alpha)$ пірен, фурани, діоксини, поліхлордіфеніли та інші. Саме тому нами була приділена увага вмісту у відпрацьованих та очищених за запропонованою схемою оливах важких металів та хлорвмісних сполук, які і формують негативний токсикологічний профіль цих відходів.

Була проведена перевірка свіжих, відпрацьованих та відновлених за запропонованими нами схемами оливи М-14B 2 на вміст в них бенз $(\alpha)$ пірену, важких металів (свинцю, нікелю, купруму, кобальту, хрому, цинку) та хлорид-іонів.

Варто відзначити, що якісне визначення хлору проводилось по зеленому забарвленню полум'я при внесенні в нього мідної проволоки 3 оливою. Це дозволяє виявити присутність елементу в кількості не менше $0,3 \%$.

Також при проведенні досліджень, що проводився у ліцензованій спеціалізованій лабораторії Державного управління охорони навколишнього природного середовища в Дніпропетровській області, для визначення бенз $(\alpha)$ пірену використовувалась методика рідинної хроматографії; для визначення важких металів - метод атомно-абсорбційної спектроскопії. Отримані результати наведені в таблиці 2.

Таблиця 2

Порівняння екологічних показників свіжих, відбракованих та відновлених олив М-14В2

\begin{tabular}{|c|c|c|c|c|c|c|c|c|}
\hline \multirow[b]{3}{*}{ Вміст в оливі } & \multicolumn{8}{|c|}{ Показник } \\
\hline & \multirow[b]{2}{*}{$\begin{array}{c}\text { Бенз(к) } \\
\text { пірен, } \\
\text { мг/кг }\end{array}$} & \multirow[b]{2}{*}{$\begin{array}{l}\text { Хлорид- } \\
\text { іон }\end{array}$} & \multicolumn{6}{|c|}{$\begin{array}{c}\text { Важкі метали } \\
\text { (валова кількість, мг/кг): }\end{array}$} \\
\hline & & & $\stackrel{\hat{\theta}}{\hat{\theta}}$ & 苞 & 音 & 包 & $\sum_{\overline{0}}^{\bar{L}}$ & $\underline{\Xi}$ \\
\hline У свіжій & - & Відс. & 35 & - & 12 & - & - & - \\
\hline У відбракованій & 13 & Відс. & 69 & 26 & 34 & - & - & 24 \\
\hline У відновленій & - & Відс. & 12 & 4 & 5 & - & - & 3 \\
\hline
\end{tabular}


Після обробки отриманих даних нами були зроблені наступні висновки:

1.Бенз $(\alpha)$ пірен з'являється при роботі олив обох марок, і він повністю зникає з них після обробки за запропонованими схемами;

2. Хлорид-іони відсутні в оливах на всіх стадіях, що підтверджує їх безпечність та екологічність запропонованих схем відновлення;

3.Важкі метали присутні у відпрацьованих оливах, що підвищує їх екологічну небезпеку, а також говорить про незадовільну роботу дизелів (відповідно до рекомендацій Організації співдружності залізниць) Значне зниження кількості цих токсичних елементів (свинцю на $82,61 \%$; нікелю на 84,62\%, купруму на 85,29\%, цинку на 87,50\%; для оливи М-14Г 2 ЦС - свинцю на 88,24\%, нікелю на 86,67\%, купруму на $84,09 \%$, хрому на $83,33 \%$, цинку на $90,91 \%$ ) після обробки олив за запропонованими схемами підтверджує безпечність відновлених олив та екологічність самих схем [3, с. 100-101; 13, с. 147-148].

Таким чином, шляхом впровадження запропонованої схеми вирішуються наступні екологічні проблеми залізниць:

- мінімізується кількість відпрацьованих олив - основного за об'ємом відходу підприємств локомотивного господарства;

- відбувається повернення цінної сировини (оливи) у технологічний процес у вигляді відновленої моторної оливи;

- отримані відновлені оливи не мають такої ж ступені токсичності, як відпрацьовані оливи, а тому не становлять загрози для довкілля.

На основі запропонованої схеми також розроблена і запропонована еколого-хіммотологічна схема поводження 3 відпрацьованими оливами (на прикладі оливи М-14В 2 ) на залізниці (рис. 5).

\section{7. Висновки}

1. Досліджені основні показники, які формують токсикологічний профіль нафтовміщуючих відходів.

2. Проаналізовані міжнародні конвенції, домовленості та вимоги щодо складу та поводження з нафтовмісними відходами.

3. Проведені експериментальні дослідження по відновленню олив 3 використанням різних методів.

4. Випробуваний метод очищення відпрацьованих олив 3 використанням різних типів поверхнево-активних речовин (ПАР) та 


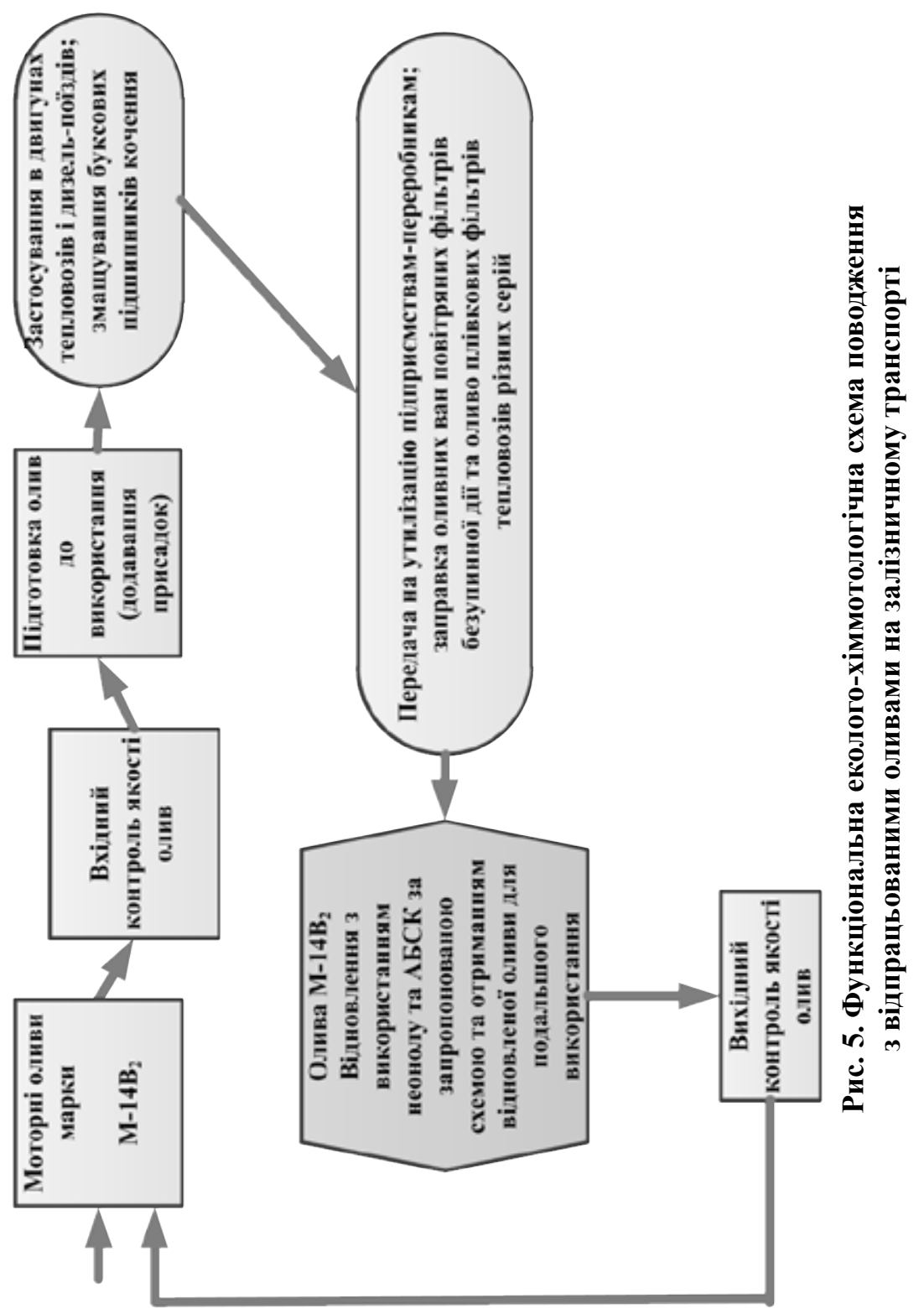


замінника сульфатної кислоти - алкілбензосульфокислоти (АБСК). Найкращий результат досягається сумісним використанням ПАРи неонолу та АБСК.

5. Досліджені екологічні показники якості свіжих, відбракованих та очищених за запропонованою схемою олив. Виявлено значне зменшення кількості або повну ліквідацію присутності у відновлених оливах важких металів, хлоридів та бенз( $\alpha)$ пірену.

6. Запропонована схема відновлення відпрацьованих олив, яка сприятиме підвищенню екологічності використання відпрацьованих моторних олив залізниць. Такі заходи мінімізують кількість відходів, знизять навантаження на навколишнє природне середовище відпрацьованих олив та дозволять отримати певний економічний ефект.

7. На основі запропонованої схеми також розроблена і запропонована еколого-хіммотологічна схема поводження 3 відпрацьованими оливами на залізниці.

8. Отримані результати досліджень можливо використати у подальшій роботі, зокрема підборі устаткування та проведенні подальших стендових та промислових випробувань.

\section{Список літератури:}

1. Катрушов О.В. Патогенна дія відпрацьованих моторних масел: недооцінена небезпека / О.В. Катрушов, В.О. Костенко, І.В. Батухіна [та ін.] // Актуальні проблеми сучасної медицини: Вісн. Української мед. стоматол. академії. - 2009. - Т. 9, № 3. - С. 188-193.

2. Ssempebwa J. Waste crankcase oil: an environmental contaminant with potential to modulate estrogenic responses / J. Ssempebwa, D. Carpenter, B. Yilmaz [et al.] // J. Toxicol. Environ. Health. - 2004. - V. 67, № 14. - P. 1081-1094.

3. Зеленько Ю.В., Тарасова Л.Д., Безовська М.С. Підвищення рівня екологічної безпеки при поводженні з відпрацьованими моторними оливами залізничної інфраструктури: [монографія] / Ю.В. Зеленько, Л.Д. Тарасова, М.С. Безовська. - Д. : Вид-во «Літограф», 2016. - 150 с.

4. The Assessment of Negative Impact of Oil Products on Railroad Track and Rolling Stock Constructions/Yu. Zelenko, O. Lunys, L. Neduzha, S. Steišūnas//Proc. of 23rd Intern. Scientific Conf. «Transport Means. 2019». - 2019. - P. 1300-1306.

5. Мямлін С.В. Параметрична екологія на залізничному транспорті. Принципи, оцінка, контроль, безпека: Монографія / С.В. Мямлін, Ю.В. Зеленько, Л.О. Недужа. - Д. : Літограф, 2014. - 203 с.

6. Plakhotnik V.N., Onyshchenko Ju.V., Yaryshkina L.A. The environmental impacts of railway transportation in the Ukraine, Transportation Research Part D: Transport and Environment. - 10(3). - 2005. - P. 263-268. 
7. Zelenko Yu. Scientific foundation of management of the environmental safety of oil product turnover in railway transport / Zelenko Yu., Myamlin S., Sandovskiy М. - Д. : Издательство Литограф, 2014. - 332 с.

8. Klimenko, I. Parameter Optimization of the Locomotive Running Gear / I. Klimenko, J. Kalivoda, L. Neduzha // Proc. of 22nd Intern. Scientific Conf. «Transport Means. 2018». - 2018. - P. 1095-1098.

9. Kalivoda, J., Neduzha, L. (2019). Simulation of Safety Against Derailment Tests of an Electric Locomotive. Proc. of 25th Intern. Conf. «Engineering Mechanics 2019», - P. 177-180. doi: 10.21495/71-0-177

10. Lunys, O. Stability Research of the Main-Line Locomotive Movement / O. Lunys, L. Neduzha, V. Tatarinova // Proc. of 23rd Intern. Scientific Conf. «Transport Means. 2019». - 2019. - P. 1341-1345.

11. Татарінова В.А. Застосування програмних комплексів при дослідженні стану транспортних засобів / В.А. Татарінова, Я. Калівода, Л.О. Недужа // Вісник сертифікації залізничного транспорту. - 2018. - № 04 (50). - С. 82-91.

12. Зеленько Ю.В. Розробка інноваційних ресурсозберігаючих технологій утилізування нафтовміщуючих відходів / Ю.В. Зеленько, М.С. Безовська, А.Л. Лещинська // Журнал «Технологический аудит и резервы производства» / За ред. Дмитрімова В.П., Дуднікова А.А., Біловода О.І. [та ін.]. - Харків : ПП «Технологічний центр», 2013. - № 1/2(9). - С. 17-21.

13. Безовська М.С. Новітні еколого-хіммотологічні моделі поводження 3 відпрацьованими оливами залізниць / М.С. Безовська, Ю.В. Зеленько // Общегосударственный научно-технический журнал «Вопросы химии и химической технологии» / Под ред. Николаенко Н.В., Баштаника П.И., Начовного И.И. - Днепропетровск : «Новая идеология», 2012. - № 1. - С. 145-148.

\section{References:}

1. Katrushov A.V., Kostenko V.A., Batuhina I.V., Solovjova N.V., Filatova V.L. (2009). Pathogenous effect of used motor oil: underestimated contamination hazard. Actual Problems of the Modern Medicine: Bulletin of Ukrainian Medical Stomatological Academy. Vol. 9, № 3. P. 188-193.

2. Ssempebwa J., Carpenter D., Yilmaz B. [et al.] (2004). Waste crankcase oil: an environmental contaminant with potential to modulate estrogenic responses. J. Toxicol. Environ. Health. Vol. 67, № 14. P. 1081-1094.

3. Zelenko Yu.V., Tarasova L.D., Bezovska M.S. (2016). Pidvyshhennja rivnja ekologhichnoji bezpeky pry povodzhenni z vidpracjovanymy motornymy olyvamy zaliznychnoji infrastruktury: monoghrafija [Improvement of the level of environmental safety in the management of waste engine oils of railway infrastructure: monograph]. Dnipropetrovsk: Lithographer Publ. (in Ukrainian)

4. Zelenko Yu., Lunys O., Neduzha L., Steišūnas S. (2019). The Assessment of Negative Impact of Oil Products on Railroad Track and Rolling Stock Constructions. Proc. of 23rd Intern. Scientific Conf. «Transport Means. 2019» (Lithuania, Palanga, October 2-4, 2019). P. 1300-1306. 
5. Myamlin S.V., Zelenko Yu.V., Neduzha L.O. (2014). Parametric environment in railway transport. Principles, assessment, monitoring, security: monograph. Dnipropetrovsk: Lithographer Publ. (in Ukrainian)

6. Plakhotnik V.N., Onyshchenko Ju.V., Yaryshkina L.A. (2005). The environmental impacts of railway transportation in the Ukraine, Transportation Research Part D: Transport and Environment. № 10(3). P. 263-268.

7. Zelenko Yu., Myamlin S., Sandovskiy M. (2014). Scientific foundation of management of the environmental safety of oil product turnover in railway transport. Dnipropetrovsk: Lithographer Publ.

8. Klimenko I., Kalivoda J., Neduzha L. (2018). Parameter Optimization of the Locomotive Running Gear. Proc. of 22nd Intern. Scientific Conf. «Transport Means. 2018» (Lithuania, Trakai, October 3-5, 2018). P. 1095-1098.

9. Kalivoda, J., Neduzha, L. (2019). Simulation of Safety Against Derailment Tests of an Electric Locomotive. Proc. of 25th Intern. Conf. «Engineering Mechanics 2019» (Czech Republic, Svratka, May 13-16, 2019). P. 177-180.

10. Lunys O., Neduzha L., Tatarinova V. (2019). Stability Research of the MainLine Locomotive Movement. Proc. of 23rd Intern. Scientific Conf. «Transport Means. 2019» (Lithuania, Palanga, October 2-4, 2019). P. 1341-1345.

11. Tatarinova V.A., Kalivoda J., Neduzha L.O. (2018). Zastosuvannja proghramnykh kompleksiv pry doslidzhenni stanu transportnykh zasobiv [Application of Software Tools in the Research of Vehicles]. Вісник сертифікації залізничного транспорту. № 04(50). Р. 82-91.

12. Zelenko Yu.V., Bezovska M.S., Leshchynska A.L. (2013). Rozrobka innovacijnykh resursozberighajuchykh tekhnologhij utylizuvannja naftovmishhujuchykh vidkhodiv [Development of innovative resource-saving technologies for the disposal of oil-containing waste]. Technology audit and production reserves. № 1/2(9). P. 17-21.

13. Bezovska M.S., Zelenko Yu.V.(2012). Novitni ekologho-khimmotologhichni modeli povodzhennja z vidpracjovanymy olyvamy zaliznycj [Newest ecological and chemotological models of railways waste oil treatment]. The Issues of Chemistry and Chemical Technology. № 1. P. 145-148. 